logos_i_ethos_2014_2_(37), s.177-201

DOI: http://dx.doi.org/10.15633/lie.802

\title{
Kazimierz Gryżenia SDB Prawo i etyka czynnikami
kształtującymi wolność osoby ludzkiej
}

\section{Uwagi wstępne}

Wolność w powszechnym przekonaniu to możliwość wyboru, przeciwieństwo determinizmu. W słownikowym i encyklopedycznym określeniu oznacza niezdeterminowane działanie człowieka, niezależność od czynników zewnętrznych, od skrępowania i przymusu fizycznego, psychicznego, moralnego, prawnego itp. ${ }^{1}$. Niektóre współczesne ten-

Kazimierz Gryżenia SDB (Uniwersytet Kardynała Stefana Wyszyńskiego) - doktor filozofii, absolwent KUL, wykładowca UKSW i Wyższego Seminarium Duchownego Towarzystwa Salezjańskiego w Lądzie n. Wartą. Członek Polskiego Towarzystwa Tomasza z Akwinu (Oddział Società Internazionale Tommaso d'Aquino), Towarzystwa Naukowego Franciszka Salezego, Towarzystwa Pedagogiki Filozoficznej oraz redakcji czasopisma "Seminare. Poszukiwania Naukowe". W badaniach naukowych zajmuje się filozofią wychowania i historią filozofii, $\mathrm{z}$ tego zakresu wydał kilkadziesiąt publikacji. dencje myślowe w gloryfikacji wolności idą tak daleko, że przypisują człowiekowi wolność absolutną, bezwzględną, która nie zna jakichkolwiek ograniczeń, co w konsekwencji prowadzi do dowolności czy wręcz swawoli. Tendencje te zmierzają w radykalnie odwrotnym kierunku niż determinizm. Odbiegają także od ujęć filozofii klasycznej, w której wolność należy wprawdzie do konstytutywnych elementów każdego człowieka, jest niezbywalną jego własnością, cechą należącą do jego istoty, ale nie znaczy to, że nie podlega ona pewnym ograniczeniom ${ }^{2}$.

Por. Mały słownik terminów i pojęć filozoficznych, oprac. A. Podsiad, Z. Więckowski, Warszawa 1983, kol. 426; J. Herbut, Wolność, [w:] Leksykon filozofii klasycznej, red. J. Herbut, Lublin 1997, s. 541-142.

2 Por. Jan Paweł II, enc. Veritatis splendor (1993), 35. 
W związku z powyższym w pojmowaniu wolności można wskazać trzy stanowiska: determinizmu, absolutnej wolności i wolności kierowanej stosownymi wskazaniami. Henryk Kiereś nazywa je odpowiednio: determinizmem, indeterminizmem i autodeterminizmem ${ }^{3}$. Ostatnie z nich, utożsamiane z filozofią i etyką klasyczną - jak się wydaje - najbardziej zabezpiecza rozwój samej wolności, a tym samym rozwój człowieka. $Z$ tej też racji będzie ono preferowane i w podjętej refleksji wiele poruszonych problemów zostanie ujętych lub ocenionych $\mathrm{z}$ tego punktu widzenia. $\mathrm{W}$ tym podejściu wolność nie jest bytowością samą w sobie, lecz jedną z charakterystycznych własności osoby ludzkiej. Wyraża się ona możliwością i zarazem koniecznością podejmowania przez człowieka decyzji, jest uprawnieniem i obowiązkiem dokonywania wyborów, co implikuje odpowiedzialność za podjęte działania i wynikające $\mathrm{z}$ nich skutki. Dzięki aktom wyboru człowiek kształtuje swoją niepowtarzalną osobowość, staje się moralnie dobry lub moralnie zły. Nie każdy więc wybór i następujące po nim działanie przynoszą pożądane rezultaty, tak dla samego podmiotu działania, jak i dla jego otoczenia. Korzystanie z wolności wiąże się z postępem w spełnianiu się osobowej natury człowieka lub z jej degradacją. Wolność, a w ślad za nią jej podmiot, podlega nieustannemu rozwojowi, wymaga więc odpowiedniej pielęgnacji i troski. W dokonującym się procesie niezbędne są kryteria i wyznaczniki. W oparciu o nie człowiek podejmuje decyzje i dokonuje autodeterminacji. Spośród wielu czynników kształtujących wolność osoby ludzkiej wybrano prawo i etykę.

\section{Wolność konstytutywnym elementem osoby ludzkiej}

Zagadnienie wolności jest ściśle związane z pojmowaniem człowieka, stanowi pochodną przyjętej antropologii. Nie jest ono łatwe do rozstrzygnięcia ze względu na wielość koncepcji antropologicznych.

3 Por. H. Kiereś, Wolność, [w:] Encyklopedia „białych plam”, red. naczelny A. Winiarczyk, t. 18, Radom 2006, s. 156. 
Jawiących się trudności nie usuwają ani też nie dają większej jasności wzmożone analizy ostatnich dwu stuleci, zwłaszcza kształtujące się pod wpływem agnostycyzmu i nihilizmu. Nie ustają więc dyskusje związane z pytaniem: kim jest człowiek, jaka jest jego natura. Jedna z koncepcji traktuje człowieka jako osobę. Battista Mondin pisze wprost, że nie ma lepszej nazwy niż osoba, by oddać kwalifikację bytu ludzkiego ${ }^{4}$. Znaczy to, że człowiek przewyższa świat przyrody, natury. Nie ma doskonalszej istoty nad człowieka. $Z$ tego tytułu żadnej rośliny ani żadnego zwierzęcia nie nazywamy osobą, tę nazwę stosujemy jedynie w odniesieniu do człowieka. Mieczysław Albert Krąpiec doda, że osoba jest nie tylko ponad przyrodą, lecz także ponad społeczeństwem. Człowiek rozpatrywany na tle tych dwóch rzeczywistości, to znaczy przyrody i społeczeństwa, jawi się jako istota transcendująca je, czyli jako byt osobowy, odznaczający się cechami nieporównywalnymi z żadnym innym bytem. Są to zdolność do intelektualnego poznania, miłowania i wyboru oraz podmiotowość wobec prawa, zupełność i godność. Pierwsze trzy cechy wskazują na wyższość człowieka w stosunku do przyrody, drugie trzy - na wyższość w stosunku do społeczeństwa. Wszystkie one nie występują oddzielnie, lecz wzajemnie się uzupełniają i determinują, wyrastają bowiem z jednego podmiotu, charakteryzują go i tworzą ${ }^{5}$.

4 Por. B. Mondin, Wolność jako istotny i pierwotny czynnik konstytutywny osoby ludzkiej, przeł. P. Kawalec, „Człowiek w Kulturze. Pismo Poświęcone Filozofii i Kulturze” [dalej: CwK] $1997 \mathrm{nr}$ 9, s. 83.

Problematykę osoby Krąpiec omawia w wielu swoich pracach: Człowiek jako osoba, Lublin 2005, s. 129-132; tenże, Człowiek bytem osobowym, [w:] Osoba i realizm $w$ filozofii, red. A. Maryniarczyk, K. Stępień, Lublin 2002, s. 19-46 (Zadania Współczesnej Metafizyki, 3/4); Osoba ludzka i błędy w jej rozumieniu, [w:] Błąd antropologiczny, red. A. Maryniarczyk, K. Stępień, Lublin 2003, s. 13-48 (Zadania Współczesnej Metafizyki, 5); O człowieku jako osobie, [w:] Osoba i uczucia, red. A. Maryniarczyk, K. Stępień, P. Gondek, Lublin 2010, s. 17-38 (Zadania Współczesnej Metafizyki, 12); Rozumienie człowieka - od hinduizmu do New Age, [w:] Dusza - Umyst - Ciało. Spór o jedność bytową człowieka, red. A. Maryniarczyk, K. Stępień, Lublin 2007, s. 17-41 (Zadania Współczesnej Metafizyki, 9); Ja - człowiek. Zarys antropologii filozoficznej, Lublin 1979; Osoba i społeczność, „Zeszyty Naukowe Katolickiego Uniwersytetu Lubelskiego” 23 (1980) nr 4, s. 17-27; Odzyskać świat realny, Lublin 1993, s. 579-706; Człowiek i prawo naturalne, Lublin 1986, s. 137155. Krótką charakterystykę tej koncepcji przedstawiłem w artykule: K. Gryżenia, Etyczne implikacje (nie)osobowego traktowania człowieka, „Forum Pedagogiczne” 2011 nr 2, s. 73-80. 
Wolność w tym ujęciu nie jest zarezerwowana dla jednej grupy społecznej, w przeciwieństwie do niewolników, nie jest wolnością zewnętrzną, typu społeczno-politycznego, lecz należy do istoty bytu osobowego, jest jego konstytutywnym i pierwotnym elementem. Bez wolności nie ma osoby ludzkiej. Człowiek jest wolny nie dzięki pochodzeniu, nie jako obywatel danego kraju lub jako członek określonego narodu, kasty czy klasy społecznej, nie w zależności od wieku lub stanu zdrowia, lecz ze względu na swą ontyczną strukturę, z samego faktu zaistnienia, dlatego że jest osobą. Wolność związana z życiem osobowym to posiadanie samego siebie, zdolność samostanowienia, to bycie źródłem i przyczyną swych działań. Jest to umiejętność panowania nad samym sobą, swoim postępowaniem w obliczu trudności, bólu, namiętności itp. ${ }^{6}$. Wyraża się ona w aktach decyzyjnych, poprzez które podmiot tych aktów rozwija się jako osoba, czyli aktualizuje swe potencjalności, spełnia się. Proces ten dokonuje się zawsze w kontekście społecznym, w relacji do innych osób. Społeczność jest dla osoby naturalnym i koniecznym środowiskiem rozwoju. Wolność jako istotna cecha osobowa, wyróżniona w relacji człowieka do przyrody, łączy się ściśle z cechą podmiotowości prawa, czyli cechą dostrzeżoną na tle analizy bytu ludzkiego w stosunku do społeczeństwa.

Życie każdej społeczności, niezależnie od jej liczebności, bogactwa struktur i organizacji, reguluje się mnóstwem przepisów prawnych, które są adresowane do każdego z jej członków. W reakcji na prawo ujawnia się wolność człowieka, który - po uprzednim rozeznaniu - może je przyjąć i realizować albo też odrzucić. Społeczności i wydawane przez nie prawa winny służyć dobru osoby i jej pełnemu rozwojowi. Może się jednak zdarzyć, że społeczności utrudniają lub uniemożliwiają wolną aktualizację potencjalności ludzkich, gdy ograniczają możliwość kształcenia, podejmowania aktów wolitywnych, uczuciowych czy religijnych. Fakty historyczne świadczą, że społeczności mogą mieć charakter i struktury antyludzkie, które uniemożliwiają podejmowanie w pełni

$6 \quad$ Por. P. Skrzydlewski, Cywilizacyjne zagrożenia życia osobowego na przykładzie zagrożeń ludzkiej wolności, CwK 2000 nr 13, s. 225-226; P. Jaroszyński, Etyka. Dramat życia moralnego, Warszawa 1997, s. 10. 
wolnych decyzji. Człowiek jest w nich postrzegany jako narzędzie, źródło siły fizycznej, przedmiot służący jakiejś ideologii lub jako mało znaczący egzemplarz stada ludzkiego, a nie jako suweren, podmiot, osoba, dla której istnieje byt społeczny. Administracyjny i prawny przymus jest po prostu nie-ludzki. Krąpiec mocno podkreśla, że wymuszenie przestrzegania wydanego prawa nie stanowi normy postępowania osobowego. Człowiek pozbawiony możliwości podejmowania decyzji lub ograniczony w swej suwerenności wykonuje wprawdzie wydane rozporządzenia, ale czyni to jak zwierzęta lub niewolnicy, którzy bezmyślnie spełniają wolę swego pana. W takich sytuacjach człowiek jest traktowany jedynie jako adresat, czyli przedmiot prawa, działa jak automat, a nie jako istota świadoma, wolna i odpowiedzialna. Człowieka jako istoty wolnej nic nie może „od zewnątrz” zdeterminować, żadne przepisy prawne nie są w stanie zmusić go do określonego działania, lecz on sam „od wewnątrz" dokonuje aktu samodeterminacji, gdy poznaje i dobrowolnie uznaje przepisy prawne za wyznacznik swego działania. Człowiek jest bowiem podmiotem prawa, znaczy to, że on sam adresowane do niego prawo musi poznać, a następnie zdecydować się na jego akceptację i przestrzeganie lub też jego odrzucenie. Dopóki norma prawna nie zostanie poznana i zaakceptowana przez osobę, pozostaje martwą literą. Właściwa promulgacja prawa dokonuje się we wnętrzu człowieka, w jego akcie decyzyjnym, w momencie autodeterminacji, czyli rozumnego i dobrowolnego wyboru, uświadomionej akceptacji ${ }^{7}$.

Wolność człowieka zasadniczo i właściwie rozgrywa się w jego wnętrzu, w konkretnej decyzji. Decyzja jest więc istotnym przejawem

Por. M. A. Krąpiec, Człowiek jako osoba, s. 130-131; por. także tenże, O człowieku jako osobie, s. 36-37; tenże, Substancja - istota - natura. Ich rozumienie i funkcja w wyjaśnianiu rzeczywistości, [w:] Substancja - Natura - Prawo naturalne, red. A. Maryniarczyk, K. Stępień, P. Gondek, Lublin 2006, s. 35-36 (Zadania Współczesnej Metafizyki, 8); tenże, Substancja - istota - natura, [w:] Powszechna encyklopedia filozofii, t. 9, red. A. Maryniarczyk, Lublin 2008, s. 259-261; M. Rozkoš, Prawo naturalne czy konwencja podstawa prawa stanowionego, [w:] Substancja - Natura-Prawo naturalne, s. 339-340. W oparciu o powyższe prace problem wolności osoby ludzkiej poruszyłem w następujących opracowaniach: K. Gryżenia, Etyczne implikacje (nie)osobowego traktowania człowieka, s. 76-78; tenże, Prawo stanowione a moralność w państwie demokratycznym, „Studia Philosophica Wratislaviensia” 2013 vol. VIII fasc. 1, s. 38-41. 
życia osobowego, ludzkiej osobowości. Wewnętrzna akceptacja prawa jest nieodzowna, a chwila jego „przyjęcia” na „swoją osobistą własność" jest wyrazem poddania się prawu. W tym momencie człowiek identyfikuje się z prawem, wiąże się z nim „od wewnątrz”, heteronomię prawa przekształca $\mathrm{w}$ autonomię ${ }^{8}$. Nigdy jednak nie można powiedzieć, że człowiek będzie działał - jak inne gatunki - w ściśle określony, czyli zdeterminowany sposób. Za każdym razem dokonuje on samodzielnego aktu wyboru. $Z$ tego aktu nikt i nic nie może go zwolnić ani go w nim wyręczyć. Rezygnacja z niego przekreślałaby lub pomniejszała człowieczeństwo człowieka, stanowiłaby poważny uszczerbek w jego osobowym życiu i rozwoju. Proces wychowawczy, w którym rodzice lub wychowawcy wyręczają lub ograniczają dziecko w podejmowaniu przez nie decyzji, nie prowadzi do pełnej jego dojrzałości. Zadaniem instytucji wychowawczych, jak zresztą każdej społeczności, jest pomoc we właściwym rozeznaniu dobra oraz skutków wynikających z podejmowanych działań, każdy jednak wychowanek czy obywatel danej społeczności musi sam decydować i ponosić odpowiedzialność. Osobista decyzja jest koniecznością, jest ona wyrazem wolności osoby, jej uprawnieniem i obowiązkiem zarazem: „W dziedzinie ludzkiej decyzji - pisze Krąpiec - wszystkie osoby są równe, wszystkie osoby są skazane na decyzję, albowiem nawet decyzja o niepodejmowaniu przez siebie decyzji jest już decyzją i spełnianiem się ludzkiej wolności”".

Takie pojmowanie wolności, z punktu widzenia koncepcji naturalistycznej prezentowanej przez starożytnych Greków czy też niektóre nowożytne teorie, jak np. teoria ewolucji, wydaje się być postulatem zbyt arbitralnym, wręcz niedorzecznym. Sprzeciwia się bowiem prawom natury, które mają charakter zdeterminowany. Człowiek - na gruncie tego sposobu myślenia - nie jest innym jestestwem w stosunku do przyrody, działa w oparciu o te same prawa, jest on „produktem” natury, z której

Por. M. A. Krąpiec, Człowiek i prawo naturalne, s. 237-238.

9 Tenże, Człowiek jako osoba, s. 124; por. także J. W. Gałkowski, Ł. Kanafa, Społeczeństwo obywatelskie a moralność, „Annales. Etyka w Życiu Gospodarczym” 2010 t. 13 nr 1, s. 69-75. 
wywodzą się prawa biologiczne, będące u podstaw wszelkiego działania człowieka. Wolność jest więc złudzeniem ${ }^{10}$.

Owszem, od natury nie da się uciec. Mówi się o naturze ludzkiej, analogicznie jak o naturze konia, kota, pszczoły czy mrówki. Wiele z tego, co stanowi istotę człowieka, pochodzi z natury. Aspekt somatyczny i biologiczny jego istnienia jest efektem sił naturalnych, które z góry przesądzają, że ma on określony kod genetyczny, organy i władze, które służą przekazywaniu i podtrzymywaniu życia. Również pewne działania, tak somatyczne, jak i psychiczne, są uwarunkowane prawami natury.

Poprzestanie na takim doświadczeniu i podkreślanie tylko tego aspektu życia i działania człowieka jest daleko idącym redukcjonizmem. Już Boecjańska definicja człowieka jako osoby: individua substantia rationalis naturae, trafnie podkreślała, że jednostkowość rozumnej natury różni ją znacząco w stosunku do jednostkowości natury „końskiej”, „kociej”, „pszczelej” czy „mrówczej”. Poszczególne jednostki tych klas bytów są tylko egzemplarzami ogólnej natury swego gatunku. Ich istnienie i działanie jest efektem powielenia określonego wzorca, projektu, jest kierowane jedynie instynktem, zdeterminowane przez naturę gatunkową. Stąd koń zawsze będzie działał „po końsku”, kot „kocio” itd. Człowiek jako osoba, czyli istota wolna, nie poddaje się całkowicie instynktom i popędom, potrafi postępować nawet wbrew naturalnym poruszeniom, nie musi działać pod dyktando potrzeb natury gatunkowej, wymogi natury poddaje logice ducha. Dzięki zdolności wyboru, od wewnątrz dokonuje aktu samodeterminacji. Nie poddaje się naturze, nie jest przez nią kierowany, lecz ją kształtuje i organizuje w sposób świadomy i dobrowolny.

Wszystko to oznacza, że człowiek nie jest tylko „produktem” natury, jest także bytem kulturowym, to znaczy, że w swoim rozwoju czerpie z dorobku minionych pokoleń, a przez swoją działalność przyczynia się do jego pomnożenia. Kultura jest łatwo zauważalną dziedziną, która

10 Por. B. Mondin, Wolność jako istotny i pierwotny czynnik konstytutywny osoby ludzkiej, s. 82-83. 
odróżnia człowieka od zwierząt i roślin. Te ostatnie nie tworzą kultury, działają w sposób całkowicie zdeterminowany przez naturę, człowiek $\mathrm{w}$ dużej mierze tworzy tę naturę, jest w stanie ją uprawiać i przekształcać wedle własnych potrzeb. Kultura nie jest czymś akcydentalnym w życiu człowieka, lecz należy do jego istoty.

Z powyższych rozważań wynika, że człowiek przetwarza nie tylko naturę, która jest poza nim, ale także - co należy mocno podkreślić - przetwarza naturę, która jest w nim. Można wskazać dwa wymiary działania człowieka: jeden, w którym przedmiotem działania są rzeczy zewnętrzne, drugi zaś, w którym przedmiotem działania jest on sam, podmiot działania. Efektem działania pierwszego są dobra kultury i osiągnięcia cywilizacyjne, efektem drugiego działania jest doskonałość osobowa, czyli człowiek wszechstronnie wykształcony, twórczy, odznaczający się mnóstwem sprawności moralnych. Można powiedzieć, że człowiek jest pierwszym odbiorcą kultury, jej twórcą i największym jej dziełem. W tym względzie John S. Mill stwierdza, że „spośród dzieł, na doskonaleniu i upiększaniu których ludzie słusznie spędzają życie, najdonioślejszym jest z pewnością sam człowiek" ${ }^{11}$. To dzieło realizuje się dzięki wysiłkowi własnych rąk i intelektu. Człowiek, podejmując ten trud, aktualizuje tkwiące w nim potencjalności, urzeczywistnia się, spełnia się jako osoba ${ }^{12}$.

Dzieje się tak dlatego, że człowiek jest wolny. Bez wolności nie ma odpowiedzialności ani moralności. Zobrazowaniem tej prawdy jest powiedzenie: libertas est conditio essendi moralitatis. Mondin za św. Tomaszem z Akwinu powtarza, że wolność sprawia, iż każdy czyn podlega ocenie moralnej, a w związku z tym napominanie, rozkazywanie, prośba i obwinianie znajdują swe uzasadnienie. Znaczy to, że każdy człowiek ponosi odpowiedzialność za swoje decyzje i czyny. Pełny jego rozwój lub też regres jest następstwem długiego łańcucha wolnych i osobistych

11 J. S. Mill, O wolności, tłum. z ang. A. Kurlandzka, [w:] tegoż, Utylitaryzm. O wolności, wstęp T. Kotarbiński, Warszawa 1959, s. 201.

12 Por. B. Mondin, Wolność jako istotny i pierwotny czynnik konstytutywny osoby ludzkiej, s. 84-85. 
wyborów. Wolność zatem jest nie tylko conditio essendi moralitatis, lecz także conditio essendi humanitatis. Innymi słowy, wolność należy do istoty człowieka, aby dzięki jej używaniu mógł rozwijać swoje człowieczeństwo. Chodzi o takie pokierowanie wolnością, aby wybory i czyny doskonaliły moralnie ich podmiot, aby sprawiały, że sam człowiek staje się lepszy. Określenie norm działania, czyli określenie, co jest moralnie dobre, a co złe, wydatnie wspomaga proces doskonalenia się człowieka, pomijanie zaś czy też bagatelizowanie przepisów normatywnych przyczynia się do degradacji człowieczeństwa ${ }^{13}$. Problem ten Karol Wojtyła nazywa perfekcjoryzmem etycznym i podkreśla, że można go zasadnie wykazać tylko na gruncie filozofii bytu. Dowodem tego jest teoria Arystotelesa i św. Tomasza z Akwinu. W innych systemach filozoficznych ten aspekt zanika ${ }^{14}$.

\section{Filozoficzne uzasadnienie perfekcjoryzmu w etyce}

W filozofii Arystotelesa dobro jest zawsze związane z bytem, który jako dobro może stać się celem dążeń innego bytu. Wytwarza się specyficzna relacja jednego bytu do drugiego, gdzie jednym krańcem tej relacji jest byt-dobro-cel, drugim krańcem relacji jest byt, który dąży do dobra-celu. Dobro-cel jest konkretną realnością, czyli tym, do czego się dąży, czego się pożąda. Jeżeli jest on przedmiotem dążenia czy pożądania innego bytu, to znaczy że w jakimś aspekcie odpowiada naturze tego bytu, który zmierza do niego lub go pożąda. Zachodzi między nimi w jakimś zakresie odpowiedniość, adekwatność, która wyraża się w tym, że przedmiot dążeń udoskonala byt, który do niego dąży. Arystoteles w swoim sposobie filozofowania w punkcie wyjścia uwzględnia doświadczenie, które podpowiada, że dążenie do celu jest faktem. Ten fakt uświadamia nam, że dobro jest realną rzeczywistością, do której dąży się jako do celu. Okazuje się, że dobro-cel, będąc przedmiotem

13 Por. tamże, s. 86.

14 Por. K. Wojtyła, W poszukiwaniu podstaw perfekcjoryzmu w etyce, „Roczniki Filozoficzne" 1957 t. 5 z. 4, s. 303-317. 
pożądania, ma w sobie coś, co odpowiada naturze bytu pożądającego, co może $\mathrm{w}$ jakiś sposób naturę tego bytu w określonym zakresie udoskonalić. Tak więc $\mathrm{w}$ arystotelesowskiej filozofii dobrem jest przedmiot dążenia, czyli cel, oraz dobrem jest to, co udoskonala byt dążący do celu ${ }^{15}$.

W oparciu o tak rozumianą filozofię dobra Arystoteles budował swoją doktrynę etyczną. Jest to nauka o człowieku, który dąży do wielu dóbr, wśród których należy wskazać to dobro, które odpowiada temu, co najbardziej istotne w jego naturze, a mianowicie rozumowi. Dobro rozwijające intelekt jest zasadniczym celem życia i działania człowieka, wszystkie inne dobra to tylko środki prowadzące do celu zasadniczego. $\mathrm{W}$ takim ujęciu zdobycie dobra-celu jest równoznaczne z osiągnięciem szczęścia, które czyni również człowieka doskonałym i godnym uznania. Wojtyła, charakteryzując myśl Arystotelesa, pisze:

Jest to właśnie doskonałość moralna wyrażająca się w posiadaniu cnót, dzięki którym człowiek dążąc do różnych dóbr poza sobą realizuje wciąż to zasadnicze dobro, które tkwi w nim samym. Ono jest celem ostatecznym jego działania, dla niego powinien czynić wszystko to, cokolwiek czyni jako rozumny, świadomy byt ${ }^{16}$.

Nietrudno dostrzec, że Arystotelesa koncepcja perfekcjoryzmu w etyce ma wiele danych po temu, aby mogła zostać przeszczepiona na grunt filozofii chrześcijańskiej. Tak też się stało; do teorii Arystotelesa św. Tomasz z Akwinu nawiązywał i ją rozwijał. U obydwu filozofów zauważa się ścisły związek między dobrem a bytem. Tomasz jeszcze bardziej związał dobro z faktem istnienia bytu. Dobro nie istnieje poza bytem, jest jego doskonałością, jego charakterystyczną cechą, jest więc czymś realnie istniejącym. Istnienie decyduje o dobru, w istnieniu bytu ma swoje źródło każda jego doskonałość. Jak żaden byt (poza Bogiem) nie istnieje jako sama substancja bez przypadłości, ani tym bardziej same przypadłości bez substancji - pełnia bytu to substancja łącznie z zespołem właściwych jej przypadłości - tak również, gdy orzekamy o jego

15 Por. tamże, s. 305.

16 Tamże, s. 306. 
doskonałości, mamy na uwadze zarówno substancję, jak i przypadłości. Mówiąc o pełnym dobru bytu w określonym gatunku, orzekamy nie tylko o substancji, lecz także o wszystkich jej przypadłościach. Brak, czyli nieistnienie jakiejś potrzebnej przypadłości, jest niedoskonałością tego bytu, jest po prostu złem. Na tej podstawie o doskonałości jednostkowego człowieka można mówić tylko wówczas, gdy posiądzie on zespół właściwych sobie cech ${ }^{17}$.

$\mathrm{W}$ realistycznej koncepcji św. Tomasza z Akwinu dobro jest utożsamione $\mathrm{z}$ istnieniem bytu, $\mathrm{w}$ tym sensie każdy istniejący byt jest dobry. Wojtyła dodaje:

Dobro jest to byt, który zostaje w relacji do innego bytu; ten inny byt dąży do niego dla własnego udoskonalenia. Dobrem jest to, co udoskonala byt pod jakimś względem, co go aktualizuje, co w ramach natury niejako potęguje jego istnienie ${ }^{18}$.

Realistyczna i dynamistyczna wizja rzeczywistości stoi u podłoża perfekcjoryzmu etycznego, czyli zasady doskonalenia się każdego bytu. $\mathrm{Na}$ gruncie tej filozofii rozwój człowieka do właściwej sobie pełni jest nie tylko jego uprawnieniem, lecz także obowiązkiem i koniecznością. Człowiek dzięki swej potencjalności podlega stopniowemu i ciągłemu doskonaleniu się. Każde jego świadome i dobrowolne działanie jest aktualizacją jego natury i dlatego stanowi o jakimś aspekcie jego doskonałości. Jeżeli działa w oparciu o poznaną prawdę o dobru, to przyczynia się do moralnego doskonalenia swego bytu, w odwrotnej sytuacji pomnaża zło moralne, swoją naturę ludzką skazuje na dewaluację i zniszczenie $^{19}$.

W tym ujęciu świadomość i wolność jako istotne elementy osoby ludzkiej nie są oderwane od podmiotu, są one cechami integralnego człowieka. Doskonalenie jednego czy drugiego aspektu bytu ludzkiego jest doskonaleniem się moralnym samego podmiotu, całego bytu.

\footnotetext{
17 Por. tamże, s. 307-308.

18 Tamże, s. 308.

19 Por. tamże, s. 309.
} 
W czasach nowożytnych i współczesnych często dominowały tendencje, które świadomość czy wolę usiłowały uczynić samodzielnym bytem, oddzielając je od swego podłoża. Rozum w filozofii Immanuela Kanta został pojęty jako samodzielny podmiot działania, oderwany od bytu. Wojtyła wykazuje, że w filozofii świadomości Kanta i jego etyce powinności nie ma mowy o dobru moralnym. Dobrem jest jedynie akt świadomości, którym jest czysta powinność. W świadomości, w akcie autonomicznego samostanowienia człowiek przeżywa swą wolność. Doskonałość moralna człowieka sprowadza się do aktu samostanowienia, do autonomii, której przejawem jest doświadczenie powinności. Moralność według Kanta - poza analizą świadomości - nie odwołuje się do jakichkolwiek czynników przedmiotowych, lecz do apriorycznych form poznawczych, które mają stanowić jakąś sferę pozazmysłowego i pozazjawiskowego człowieczeństwa. Akty świadomości mają wyraźnie charakter intencjonalny, są skierowane od podmiotu do przedmiotu ${ }^{20}$.

W miejsce aprioryzmu subiektywistycznego Kanta Max Scheler wprowadził aprioryzm obiektywistyczny. Sferę obiektywistyczną stanowią różnorodne wartości. Treści myślowe nie tkwią w podmiocie, w samej świadomości, lecz poza nią. Świadomość nie jest nastawiona na aprioryczną formę, z której czerpie całą treść swoich moralnych przeżyć, jak to było u Kanta, lecz treść świadomości jest przedmiotowa i ma swe źródło w świecie dóbr. Scheler nie określa jednak, czym są te dobra same w sobie, mówi tylko, że treść świadomości to wartości bezpośrednio przeżywane przez emocjonalną sferę osoby przy zetknięciu się z przedmiotowym światem dóbr. Odmienność ujęć Schelera w stosunku do ujęć Kanta jest tylko pozorna, a jego obiektywizm pozostaje jedynie w sferze niepotwierdzonego założenia. Wartości należą do przeżyciowej strony człowieka, nie należą natomiast do samych rzeczy. Scheler wiąże wartości ze sferą przeżyciową, jeżeli doznajemy odczucia uszczęśliwiającego, to znaczy, że spotykamy się z wartością pozytywną, jeżeli zaś doznajemy emocjonalnego przygnębienia, to znak, że stykamy się 
z wartościami negatywnymi. Przeżyć tych nie sposób zobiektywizować i z czymkolwiek porównać, ponieważ należą do sfery emocji.

Z punktu widzenia etyki perfekcjorystycznej można i należy zapytać, czy wartości udoskonalają osobę. Wojtyła wykazuje, że koncepcja Schelera nie uzasadnia w pełni perfekcjoryzmu w etyce. Osoba w tej koncepcji nie jest bowiem bytem, lecz jednością przeżyć, świadomością jedności przeżyć. W każdym poszczególnym przeżyciu i odczuciu wartości współodczuwamy jedność wszystkich przeżyć i aktów. Ta uświadomiona jedność wszelkich aktów stanowi osobę, a nie obiektywny byt osobowy. Przy takim założeniu nie można zdecydowanie twierdzić, że wartości doskonalą osobę. Wartości są tylko treściami świadomości, a jako treści świadomości nie doskonalą bytu osoby.

Wartość każda, również wartość moralna - pisze Wojtyła - jest tylko przedmiotem intencjonalnym odczucia. Jednakże intencjonalne odczuwanie wartości moralnej ze strony osoby nie może być utożsamione z realnym udoskonaleniem bytu tejże osoby przez wartość moralną ${ }^{21}$.

W teoriach Kanta i Schelera świadomość jest oderwana od bytu osoby i potraktowana jako samodzielny podmiot działania. Tak ujęta świadomość jest podmiotem treści myślowych lub wartości jako jej intencjonalnych korelatów. Ich podmiotem nie jest osoba i dlatego te intencjonalne treści nie mogą doskonalić swego podmiotu, czyli osoby. Przy próbach obiektywizowania samej świadomości, bez zobiektywizowania bytu świadomego, który jest podmiotem świadomości, perfekcjoryzm w etyce nie ma uzasadnionych podstaw. We wcześniejszej filozofii bytu i dobra, czyli w filozofii Arystotelesa i Tomasza z Akwinu, świadomość wiąże się nierozdzielnie z bytem ludzkim jako swoim podmiotem i jest aktem tego podmiotu. Pełny i integralny człowiek jest bytem, a nie tylko świadomością. W tym ujęciu doskonalenie aktu poznawczego doskonali rozum, a pośrednio też i osobę. Zdaniem Wojtyły „Filozofia bytu to system realistyczny i obiektywistyczny, w którym dobro jest 
utożsamiane $\mathrm{z}$ bytem, a życie moralne jest konsekwentnie pojęte jako dzieło doskonalenia się bytu świadomego"22. Ważność i wartość tej filozofii Wojtyła - już jako Jan Paweł II, niemal u kresu swoich dni - zdecydowanie podkreśli w słowach: „Jeżeli sensownie chcemy mówić o dobru i złu, musimy wrócić do św. Tomasza z Akwinu, to jest do filozofii bytu"23. Również papież Benedykt XVI w tym samym duchu postuluje, aby „serce rozumne” było otwarte na język bytu ${ }^{24}$.

W tym punkcie rozważań przede wszystkim jest mowa o świadomości, która - aby mogła przyczyniać się do doskonałości człowieka - nie może być oderwana od obiektywnego bytu ludzkiego i potraktowana jako samodzielny podmiot działania. To, co stwierdzono w odniesieniu do świadomości, należy z całą mocą przekonania powtórzyć - zgodnie z główną myślą tych rozważań - w odniesieniu do zagadnienia wolności. W szelkie próby absolutyzowania wolności i czynienie jej samodzielną bytowością, bez związku z osobą ludzką, która jest jej podmiotem, nie wiążą się z doskonaleniem osoby, wręcz przeciwnie - są jej zubożeniem i degradacją.

\section{Absolutyzacja wolności przekreśleniem spełniania się osobowego człowieka}

W świetle powyższych rozważań nie trzeba dowodzić, że nie każde używanie wolności służy osiąganiu osobowej pełni, swoistego optimum. Owszem, może to być rozwój, ale w złym kierunku. Tę tezę potwierdza codzienne doświadczenie. Wolność bowiem jest możliwością kradzieży, oszustwa, malwersacji, niszczenia oponentów politycznych, konkurencji gospodarczej itp. Takie podejście oznacza nie tylko szkodę lub krzywdę wyrządzoną innym, lecz także przekreślenie lub poważne

22 Tamże, s. 316.

23 Jan Paweł II, Pamięć i tożsamość. Rozmowy na przełomie tysiącleci, Kraków 2005, s. 21.

24 Por. Benedykt XVI, Serce rozumne. Refleksje na temat podstaw prawa, „Nasz Dziennik" 23.09.2011, s. 12. Jest to przemówienie Benedykta XVI wygłoszone w Reichstagu 22 września 2011 roku. 
ograniczenie osobistego spełniania się człowieka jako osoby. Wolność, która nie zna prawnych lub moralnych ograniczeń, nie przyczynia się do doskonalenia się osoby ludzkiej. Taką jednak wolność proponowali Friedrich Wilhelm Nietzsche, Jean Paul Sartre, Albert Camus i wielu współczesnych postmodernistów, jak Richard Rorty, Zygmunt Bauman i inni. Według nich wolność nie jest niczym ograniczona. Człowiek poza sobą nie znajduje żadnego innego sensownego wyznacznika swego postępowania; sam dla siebie jest prawodawcą, wykonawcą, egzekutorem i sędzią. Nie znajduje żadnej instancji, przed którą miałby się „rozliczać” ze swego postępowania. Zgodnie z tytułem jednego z dzieł Nietzschego człowiek jest poza dobrem i złem. Wolność nie jest konstytutywnym czynnikiem człowieka, lecz samą istotą ludzkiej osoby. „Niemożliwe jest - deklaruje Sartre - wskazać inne ograniczenie mojej wolności niż ona sama; lub, jak ktoś woli, oznacza to, że nie jesteśmy wolni w tym, by przestać być wolnymi"25.

Zdaniem przedstawicieli tych tendencji kulturowych błędem dotychczasowej filozofii było uporczywe dążenie do uniwersalnych i niezmiennych prawd, zasad i norm, które stałyby u podstaw ludzkiej działalności. Wysiłki zmierzające do wypracowania obiektywnej wizji rzeczywistości spełzły na niczym. Trzeba porzucić wszelkie dążenia do obiektywności i racjonalności, zrezygnować z budowania systemów filozoficznych, religijnych, politycznych, etycznych, pedagogicznych itp. Każdy z nich jest tylko wyrazem subiektywnych odczuć. Należy przyjąć, że rzeczywistość, w tym także człowiek, jest splotem nieprzeniknionej wieloznaczności i przypadkowości. Jesteśmy skazani na nieprzejrzysty labirynt różnorodności i pluralizmu ${ }^{26}$. W związku $\mathrm{z}$ tym nie istnieje obiektywna i uniwersalna prawda oraz jednolite normy, zasady, wartości. Wszelkie dążenia do uniwersalizmu i obiektywizmu - twierdzi

25 Cyt. za B. Mondin, Wolność jako istotny i pierwotny czynnik konstytutywny osoby ludzkiej, s. 87; por. także H. Kiereś, Wolność, s. 157.

${ }_{26}$ Por. G. Hołub, Wybór należy do ciebie? - Pomiędzy obiektywnym a subiektywnym rozumieniem dobra, „Cywilizacja” 2004 nr 10, s. 67-75; K. Gryżenia, Odmienność współczesna norma - wybrane ujęcia filozofii wychowania, [w:] Wobec „odmienności...?”. Pedagogiczne konotacje, red. M. Dycht i L. Marszałek, Warszawa 2008, s. 37-44. 
Bauman - doprowadziły do totalitaryzmu i terroryzmu, który zaowocował nazistowskim i stalinowskim ludobójstwem. Przyczyny takiego stanu rzeczy Bauman upatruje w filozofii, która utwierdzała w przekonaniu, że rozum jest w stanie obiektywnie poznać rzeczywistość i ustalić zasady życia społecznego, co dało władcom skuteczne narzędzie rozprawiania się z ludźmi inaczej myślącymi. Tymczasem nie istnieją żadne podstawy, aby jakiemukolwiek stanowisku przyznać uprzywilejowaną pozycję. Poznaniu rzeczywistości ma towarzyszyć świadomość relatywizmu i subiektywizmu ${ }^{27}$. Prawdą dla poznającego podmiotu jest tylko to, co on uzna za sensowne i wartościowe. Każdy stanowi sam o prawdzie i normach swego postępowania. W rezultacie, ile ludzi, tyle możliwych prawd i norm działalności ${ }^{28}$. Nie istnieje żadna nauka, która przynosiłaby rozstrzygające rezultaty, żadne rozwiązanie nie może stać się uniwersalnym wzorcem dla wszystkich ludzi. Od tej reguły nie ma wyjątków - twierdził Rorty ${ }^{29}$.

Zgodnie z powyższymi założeniami, zwłaszcza subiektywizmu i relatywizmu, etykę należy uprawiać po wyzbyciu się ciasnego i krępującego gorsetu prawdy, dobra, wartości i norm obiektywnych. Bauman wykazuje, że etyka dawna, będąca zbiorem norm i przepisów prawnych regulujących życie społeczne, kierowała się heteronomicznym przymusem, który z zewnątrz sterował życiem człowieka, tym samym niszcząc jego wolność i autonomię ${ }^{30}$. Tejże etyce towarzyszył lęk przed wolną wolą, czyli błędne przekonanie, że jeżeli postępowania człowieka nie ujmie się w ramy ustalonych przepisów, to człowiek będzie podejmował tylko

27 Por. Z. Bauman, Wieloznaczność nowoczesna, nowoczesność wieloznaczna, przeł. z ang. J. Bauman, Warszawa 1995, s. 34-78; por. także H. Kiereś, Postmodernizm, [w:] Z badań nad filozofia najnowszą, red. A. Bronk, Lublin 1995, s. 265-266; P. Czarnecki, Postmodernizm czyli koniec filozofii?, „Parerga” 2004 nr 2, s. 22.

28 Por. Z. Sareło, Postmodernizm w pigułce, Poznań 1998, s. 3-8; por. także A. Grzegorczyk, Postmodernizm przeciwko prawdzie, „Ethos” 9 (1996) nr 1-2 (33-34), s. 150-156.

29 Por. R. Rorty, Obiektywność, relatywizm i prawda, tłum. z ang. J. Margański, Warszawa 1999 , s. 120.

30 Por. Z. Bauman, Etyka ponowoczesna, przeł. z ang. J. Bauman, J. Tokierska-Bakir, Warszawa 1996, s. 18; por. także A. L. Zachariasz, Moralność i rozum w ponowożytności, [w:] Moralność i etyka w ponowożytności, red. Z. Sareło, Warszawa 1996, s. 28-30. 
złe decyzje, będzie zagrażał dobru i unikał odpowiedzialności. Każdy czyn niezgodny z panującym zwyczajem był równoznaczny z występkiem. W takiej sytuacji - pisze Bauman - „kroczenie drogą dobra nie było kwestią wolnego wyboru: przeciwnie, wiązało się z unikaniem wyboru - z trzymaniem się zwyczajowych dróg postępowania"'31.

Tak więc etyka tradycyjna usiłowała opanować niebezpieczny żywioł wolności przez wprowadzenie powszechnie obowiązujących norm, przepisów, zwyczajów i tradycji. W tym ujęciu na kwalifikację postępowania moralnego zasługiwał ten, kto owe przepisy sobie przyswoił i według nich działał ${ }^{32}$. Zdaniem Baumana przyjęcie jakichkolwiek zewnętrznych wobec człowieka i powszechnie obowiązujących norm jest przekreśleniem możliwości podejmowania wolnej decyzji. Innymi słowy, poddanie się zewnętrznym standardom jest przyzwoleniem na jakąś formę przemocy i rezygnacją z wolności ${ }^{33}$. W tym kontekście dopuszcza się, a nawet zakłada, różnorodność działań moralnych, wręcz ich chaotyczność, ponieważ nie opierają się one na racjonalnym poznaniu świata i człowieka. Działanie ludzkie to czysty przypadek, nie ma jednolitego i obowiązującego wszystkich zestawu norm i zasad.

W tak rozumianej wolności, która nie podlega powszechnym ograniczeniom prawnym i moralnym, wszystko jest dozwolone: aborcja i eutanazja, homoseksualizm i adopcja dzieci przez związki partnerskie, łagry i gułagi. Zaciera się granica między dobrem i złem, czyny szlachetne i przestępcze są stawiane na tej samej płaszczyźnie, nawet zachowania dewiacyjne zasługują na akceptację i tolerancję. Jedynym kryterium oceny wartości działania jest subiektywne odczucie, a nawet kaprys, chwilowa zachcianka, egoistyczny impuls. Nie jest to wolność, której używanie służy wzrostowi w człowieczeństwie, lecz wolność proporcjonalna do posiadanej siły, wolność wilka lub lwa w stosunku do innych zwierząt w lesie lub buszu. Wolność bez ograniczeń przeradza się w dowolność i swawolę. W takiej postaci propagowanie jej jest nie

\footnotetext{
Z. Bauman, Etyka ponowoczesna, s. 9.

Por. tamże, s. 73.

Por. tamże, s. 12-15.
} 
tylko bezpodstawne, lecz nawet szkodliwe ${ }^{34}$. Zagrożenie to Krąpiec wyraził następująco:

Tak więc wolność nie kierowana i nie determinowana przez rozum, stała się groźną pomyłką, bowiem stała się wolnością nieodpowiedzialną, pojmowaną jako niezależność od nikogo prócz podmiotu wyłaniającego różne formy tzw. wolności ${ }^{35}$.

Tak skrajny pogląd o wolności ludzkiej jest radykalnym przeciwieństwem determinizmu. Jeden i drugi jest nie do przyjęcia, jest po prostu fałszywy. Człowiek z jednej strony nie jest całkowicie pozbawiony wolności, ani nie jest nieograniczony w jej używaniu. Wolność człowieka jest adekwatna do jego istoty, czyli bytu psychofizycznego, jest mu ona dana po to, aby rozwijał swoje człowieczeństwo, aby doskonalił się w sprawnościach moralnych poprzez panowanie nad swoimi naturalnymi pobudkami, instynktami, namiętnościami, aby właśnie jako wolny stanowił o samym sobie ${ }^{36}$.

Mondin, jako wyraziciel takiego stanowiska, potrzebę kształtowania wolności ujął w kilku punktach.

1. Wolność nie jest tożsama $\mathrm{z}$ istotą osoby ludzkiej, lecz jest jedną z jej podstawowych cech i własności obok życia, myślenia, języka, kultury itp. Podlega ona tym samym ograniczeniom i wymaga rozwoju, jak życie, myślenie, mowa, praca itd.

2. Człowiek nie jest wolny od bycia istotą cielesną, społeczną, płciową itp. Korzystając z daru wolności, nie może nie liczyć się z wymogami natury fizycznej, posiadanymi skłonnościami i popędami. Z kolei żyjąc w społeczności ludzkiej, nie może pomijać uprawnień innych osób; posługując się językiem, musi uwzględnić reguły gramatyczne i znaczenie poszczególnych słów.

34 Por. B. Mondin, Wolność jako istotny i pierwotny czynnik konstytutywny osoby ludzkiej, s. 88.

M. A. Krąpiec, Człowiek jako osoba, s. 141.

36 Por. B. Mondin, Wolność jako istotny i pierwotny czynnik konstytutywny osoby ludzkiej, s. 87. 
3. W używaniu wolności człowiek ujawnia swą ułomność i skłonność do złego, czego doświadczamy w sobie niemal każdego dnia. Ten aspekt ludzkiej kondycji domaga się, aby go uwzględnić w koncepcjach pedagogicznych i programach edukacyjnych. Tę prawdę dostrzegali i podkreślali starożytni autorzy, pogańscy i chrześcijańscy. Owidiusz pisał, że widzi dobro i je aprobuje, lecz podąża za złem, zaś św. Paweł Apostoł w podobnych słowach ubolewał w Liście do Rzymian: „Nie rozumiem tego, co czynię, bo nie czynię tego, co chcę, ale to, czego nienawidzę - to właśnie czynię. [...] Łatwo mi przychodzi chcieć tego, co dobre, ale wykonać - nie. Nie czynię bowiem dobra, którego chcę, ale czynię to zło, którego nienawidzę" (Rz 7, 15.18b-19) $)^{37}$.

W świetle powyższych spostrzeżeń człowiek nie dysponuje wolnością nieskończoną, w jej używaniu nie jest nieograniczony, jeżeli zależy mu na wzroście w swoim człowieczeństwie i wzbogaceniu swojego bytu. Odpowiednia troska w tym względzie owocuje eliminacją wad oraz pojawieniem się zespołu sprawności moralnych, czyli cnót. Wolność, która z założenia ma prowadzić człowieka do takiego stanu, wymaga - ujmując problem negatywnie - określonych ograniczeń, ujmując zaś pozytywnie - potrzebuje wsparcia i ukierunkowania, którymi są określone kryteria i punkty odniesienia.

\section{Nieodzowność norm w formowaniu wolności}

Proces doskonalenia moralnego nie dokonuje się na zasadzie przypadku, lecz jest to sprawa mądrego wyboru i umiejętności. Jest pewna doskonałość w sztuce bycia człowiekiem. Człowiek w punkcie wyjścia, jako dziecko, pozostaje „projektem” otwartym na różnorodne interpretacje i wpływy. Jest to okres bardzo ważny i wymagający szczególnej troski, ponieważ niewłaściwe pokierowanie wolnością będzie miało poważne konsekwencje wyrażające się błędnym wyborem i błędną realizacją projektu życiowego, czyli powołania. Wolność wymaga dyscypliny i troski, w przeciwnym razie działa ślepo i opacznie. Dowodzi to,

37 Por. tamże, s. 88-89. 
że istnieją normy, które człowiek winien znać, przestrzegać ich i nimi się kierować. Człowiek nie jest samowystarczalną Leibnicjańską monadą „bez okien”, lecz istotą społeczną, jego życie, wzrost i spełnianie się przebiega w społeczności, przy pomocy i współpracy z innymi ludźmi. Jednostka musi uwzględniać potrzeby innych, którzy mają te same prawa i obowiązki. Zadaniem każdej społeczności jest ustanowienie reguł używania wolności przez wprowadzenie przepisów prawnych, które z jednej strony ograniczają tę wolność, z drugiej strony są środkiem i pomocą w realizacji własnego człowieczeństwa każdego z obywateli. Prawo wspomaga więc osobę w poznawaniu zasad i kryteriów działania, których w pojedynkę prawdopodobnie nie byłaby w stanie odkryć i przyswoić. Funkcją prawa jest pomoc osobie w odnalezieniu i poznaniu zasad działania, które będą ją prowadziły do pełni autentycznego człowieczeństwa. W świetle tych stwierdzeń prawo nie może być traktowane tylko jako uciążliwe kajdany wolności, lecz jako jej przewodnik i sprzymierzeniec. Dostarcza wolności odpowiednich reguł oraz mocy w jej używaniu i realizowaniu celu, jakim jest doskonałość osobowa ${ }^{38}$.

Nadmienić trzeba, że w tym miejscu jest mowa o takim prawie, które liczy się z zasadami i normami moralnymi oraz z wymogami prawa naturalnego i natury ludzkiej. Prawo stanowione nie może mieć innej podstawy, choć wielu współczesnych autorów podkreśla autonomię prawa i moralności ${ }^{39}$, a prawo naturalne traktuje jako naukę ściśle katolicką, o której nie warto dyskutować i najlepiej nie używać tej nazwy ${ }^{40}$. Jeżeli jednak prawo chce być przewodnikiem ludzkiej wolności, winno uwzględniać naturę osoby ludzkiej i jej dobro realizujące się w prawie. Prawo jest dla człowieka, dla jego dobra i rozwoju, a nie odwrotnie. Pozbawione takiej podstawy staje się niezrozumiałe. Łatwo jest wówczas wypaczyć właściwy sens prawa, nadając mu charakter arbitralnej dyrektywy lub sprowadzając je wyłącznie do demokratycznej konwencji.

38 Por. tamże, s. 89-93.

39 Więcej na temat współczesnych dyskusji na ten temat por. K. Gryżenia, Prawo stanowione a moralność w państwie demokratycznym, s. 41-45.

40 Por. Benedykt XVI, Serce rozumne..., s. 12. 
Prawo tworzone poza etyką traci swój autorytet, nie wiąże obywateli w sumieniu; miejsce norm etycznych zajmują przepisy prawne, im mniej moralności, tym więcej przepisów. W ich gąszczu zwykli obywatele gubią się, nie są w stanie $\mathrm{z}$ nimi się zapoznać ani ich rozumieć, w konsekwencji łamią je i lekceważą ${ }^{41}$.

Tak więc, aby prawo spełniało właściwą funkcję i we właściwy sposób kierowało wolnością, nie może pomijać zasad etycznych oraz nie uwzględniać prawa naturalnego i jego boskiego źródła. Jan Paweł II wiele razy przypominał, że wolność człowieka nie jest nieograniczona, władza decydowania o dobru i złu należy wyłącznie do Boga, który polecił człowiekowi: „Z drzewa poznania dobra i zła nie wolno ci jeść” $(\mathrm{Rdz} 2,17)$. Człowiek jednak zawsze stawał przed pokusą wyrażoną słowami zwodziciela: „Tak jak Bóg będziecie znali dobro i zło” ( $\operatorname{Rdz} 3,5)$, czyli będziecie sami stanowić o tym, co jest dobrem, a co złem ${ }^{42}$.

Jan Paweł II wskazuje wprawdzie na religijny fundament problematyki dobra i zła, lecz jednak zdecydowanie stwierdza, że pomijanie Boga i bagatelizowanie Jego wskazań skutkuje dramatami ludzkimi. Według papieża

Skoro człowiek sam, bez Boga, może stanowić o tym, co jest dobre, a co złe, może też zdecydować, że pewna grupa ludzi powinna być unicestwiona. Takie decyzje, na przykład, były podejmowane w Trzeciej Rzeszy przez osoby, które po dojściu do władzy na drodze demokratycznej uciekały się do nich, aby realizować przewrotny program ideologii narodowego socjalizmu, inspirującej się przesłankami rasowymi. Podobne decyzje podejmowała też partia komunistyczna w Związku Radzieckim i w krajach poddanych ideologii marksistowskiej. W tym kontekście dokonała się eksterminacja Żydów, a także innych grup, jak na przykład Romów, chłopów na Ukrainie, duchowieństwa prawosławnego i katolickiego w Rosji, na Białorusi i za Uralem. Podobnie dokonywały się prześladowania wszystkich osób niewygodnych dla ustroju: na przykład kombatantów września 1939 roku oraz żołnierzy Armii

${ }_{41}$ Por. A. Derdziuk, Odrzucenie moralności w imię prawa, [w:] Wartości moralne w kontekście wspótczesnego sekularyzmu, red. J. Gocko, Lublin 2007, s. 18-20.

42 Por. Jan Paweł II, enc. Veritatis splendor, 35; tenże, Pamięć i tożsamość, s. 15. 
Krajowej w Polsce po II wojnie światowej, a także przedstawicieli inteligencji, którzy nie podzielali światopoglądu marksistowskiego czy nazistowskiego ${ }^{43}$.

Jan Paweł II, charakteryzując ,ideologie zła” z przeszłości, nie omieszkał poruszyć nabrzmiałych problemów dnia dzisiejszego. Pisał:

Wspomniane formy eksterminacji ustały, utrzymuje się jednak nadal legalna eksterminacja poczętych istnień ludzkich przed ich narodzeniem. Również i to jest eksterminacja zadecydowana przez demokratycznie wybrane parlamenty i postulowana w imię cywilizacyjnego postępu społeczeństw i całej ludzkości. Nie brak innych poważnych form naruszania prawa Bożego. Myślę na przykład o silnych naciskach Parlamentu Europejskiego, aby związki homoseksualne zostały uznane za inną postać rodziny, której przysługiwałoby również prawo adopcji. Można, a nawet trzeba się zapytać, czy tu nie działa również jakaś inna jeszcze „ideologia zła”, w pewnym sensie głębsza i ukryta, usiłująca nawet wykorzystać prawa człowieka przeciwko człowiekowi oraz przeciwko rodzinie ${ }^{44}$.

Tego rodzaju niepokój Jan Paweł II wyrażał i pytał o jego przyczyny. W odpowiedzi stwierdził jednoznacznie: „dzieje się to po prostu dlatego, że odrzucono Boga jako Stwórcę, a przez to jako źródło stanowienia o tym, co dobre, a co złe"45. Prawo Boże - zdaniem Jana Pawła II - nie umniejsza ani nie przekreśla wolności człowieka, przeciwnie - jest jej gwarancją i sprzyja jej rozwojowi. W przyjęciu tego prawa ludzka wolność naprawdę i w pełni się urzeczywistnia ${ }^{46}$. Pomiędzy rozumieniem wolności ludzkiej i prawem moralnym istnieją głębokie, wewnętrzne powiązania ${ }^{47}$. Tym samym Jan Paweł II negatywnie odnosi się do tych

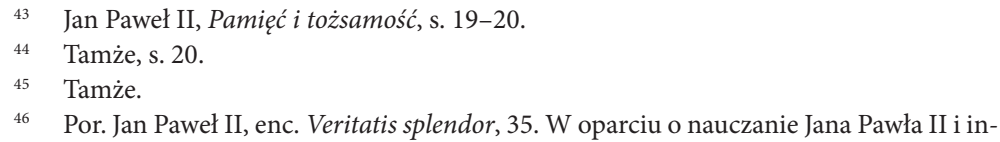
nych autorów filozofii klasycznej Piotr Moskal wykazuje, że świadome i wolne ukierunkowanie się człowieka na Boga jest najpewniejszą gwarancją jego wolności. Por. P. Moskal, Życie dla Boga fundamentem wolności, CwK 1997 nr 9, s. 73-77.

47 Por. Jan Paweł II, enc. Veritatis splendor, 37. 
doktryn, które dopatrują się rzekomego konfliktu między wolnością i heteronomicznym prawem moralnym. $Z$ tej też racji poszczególne jednostki i grupy społeczne nie mogą przyznawać sobie prawa decydowania o tym, co dobre i co złe. Człowiek nie może dowolnie tworzyć wartości i nadawać sensu rzeczom wedle własnego uznania ${ }^{48}$. Grzegorz Hołub problem konieczności kierowania się niezależnymi od człowieka kryteriami ujął następująco:

Wybór należy do ciebie, ale pamiętaj, że ilekroć wybierasz, nie możesz kierować się tylko dobrem subiektywnym, ale zawsze musisz mieć na celu obiektywne dobro dla osoby ${ }^{49}$.

\section{Wnioski końcowe}

Poczynione rozważania nie są wyczerpującym omówieniem tematu wolności, lecz tylko pewnym głosem w dyskusji. Wyłoniły one dwie przeciwstawne orientacje. Jedna z nich, będąca wyrazem współczesnych tendencji kulturowych, traktuje wolność jako bytowość samą w sobie, oderwaną od obiektywnego bytu ludzkiego. Jest to wolność nieskończona, niepodlegająca ograniczeniom, wolność wręcz absolutna. Rządzi się ona „swoimi prawami”, a właściwie ich nie ma, ponieważ nie istnieją obiektywne wartości, normy i zasady ludzkiego działania. W tym ujęciu nie ma też teoretycznych podstaw uzasadniających potrzebę moralnego doskonalenia się człowieka. Używanie wolności nie wpływa na moralny aspekt bytu ludzkiego, człowiek nie staje się przez to lepszy lub gorszy. Zbudowanie konsekwentnej doktryny perfekcjoryzmu etycznego jest niemożliwe, co więcej - niepotrzebne i zbędne. Krótko mówiąc, koncepcje, które preferują pełną autonomię wolności człowieka, sankcjonują wady i egoistyczne pobudki, nie sprzyjają więc jego rozwojowi, są nawet szkodliwe. 
Natomiast druga orientacja to stanowisko autodeterminizmu, wyrosłe z filozofii bytu, czyli filozofii realistycznej. Podkreśla ona, że wolność należy nie tylko do ontycznej struktury człowieka, lecz spełnia ważną rolę antropologiczną - jest dana po to, aby człowiek mógł się spełniać i osiągnąć sobie właściwą doskonałość bytową. Przy założeniach tej filozofii nawet nie można mówić o wolności inaczej, jak w perspektywie doskonalenia się osobowego. Zasadniczym dobrem i celem jest dobro moralne podmiotu wolności, a nie jedynie korzystanie z wolności według czysto subiektywnych odczuć. Tak więc filozofia bytu jest tą doktryną, która wykazuje potrzebę moralnego doskonalenia się człowieka przez każdy dobry czyn, czyli taki, który jest wykonywany w oparciu o ustalone zasady i normy. Do nich należą prawo stanowione i prawo moralne, którego ostatecznym źródłem jest Bóg Stwórca. Na tym między innymi polega niepodważalna pozycja tej filozofii.

\section{Bibliografia}

Bauman Z., Etyka ponowoczesna, przeł. z ang. J. Bauman, J. Tokierska-Bakir, Warszawa 1996.

Bauman Z., Wieloznaczność nowoczesna, nowoczesność wieloznaczna, przeł. $\mathrm{z}$ ang. J. Bauman, Warszawa 1995.

Benedykt XVI, Serce rozumne. Refleksje na temat podstaw prawa, „Nasz Dziennik" 23 września 2011, s. 11-12. Przemówienie Benedykta XVI wygłoszone w Reichstagu w dniu 22 września 2011 roku.

Derdziuk A., Odrzucenie moralności w imię prawa, [w:] Wartości moralne w kontekście wspótczesnego sekularyzmu, red. J. Gocko, Lublin 2007, s. $13-26$.

Gryżenia K., Etyczne implikacje (nie)osobowego traktowania człowieka, „Forum Pedagogiczne" 2011 nr 2, s. 71-96.

Gryżenia K., Odmienność współczesna norma - wybrane ujęcia filozofii wychowania, [w:] Wobec „odmienności...?”. Pedagogiczne konotacje, red. M. Dycht i L. Marszałek, Warszawa 2008, s. 36-48.

Gryżenia K., Prawo stanowione a moralność w państwie demokratycznym, „Studia Philosophica Wratislaviensia" 2013 vol. VIII fasc. 1, s. 37-50. 
Gryżenia K., Zagrożenia podmiotowości człowieka, „Logos i Ethos” 30 (2011) 1, s. 215-233.

Hołub G., Wybór należy do ciebie? - Pomiędzy obiektywnym a subiektywnym rozumieniem dobra, „Cywilizacja” 2004 nr 10, s. 67-75.

Jan Paweł II, Encyklika Veritatis splendor (1993).

Jan Paweł II, Pamięć i tożsamość. Rozmowy na przełomie tysiącleci, Kraków 2005.

Kiereś H., Wolność, [w:] Encyklopedia „białych plam”, red. naczelny A. Winiarczyk, t. 18, Radom 2006, s. 156-159.

Krąpiec M. A., Człowiek i prawo naturalne, Lublin² 1986.

Krąpiec M. A., Człowiek jako osoba, Lublin 2005.

Krąpiec M. A., O człowieku jako osobie, [w:] Osoba i uczucia, red. A. Maryniarczyk, K. Stępień, P. Gondek, Lublin 2010, s. 17-38 (Zadania Współczesnej Metafizyki, 12).

Mondin B., Wolność jako istotny i pierwotny czynnik konstytutywny osoby ludzkiej, przeł. P. Kawalec, „Człowiek w Kulturze. Pismo Poświęcone Filozofii i Kulturze" 1997 nr 9, s. 79-98.

Rorty R., Obiektywność, relatywizm i prawda, tłum. z ang. J. Margański, Warszawa 1999.

Sareło Z., Postmodernizm w pigułce, Poznań 1998.

Skrzydlewski P., Cywilizacyjne zagrożenia życia osobowego na przykładzie zagrożeń ludzkiej wolności, „Człowiek w Kulturze. Pismo Poświęcone Filozofii i Kulturze" 2000 nr 13, s. 219-236.

Wojtyła K., W poszukiwaniu podstaw perfekcjoryzmu w etyce, „Roczniki Filozoficzne" 1957 t. 5 z. 4, s. 303-317. 